\title{
A novel and efficient synthesis of phenanthrene derivatives via palladium/norbornadiene-catalyzed domino one-pot reaction
}

\author{
Yue Zhong ${ }^{1}$, Wen-Yu Wu ${ }^{2}$, Shao-Peng $\mathrm{Yu}^{1}$, Tian-Yuan Fan ${ }^{1}$, Hai-Tao $\mathrm{Yu}^{1}$, \\ Nian-Guang Li ${ }^{* 1}$, Zhi-Hao Shi ${ }^{*}$, Yu-Ping Tang ${ }^{1,4}$ and Jin-Ao Duan ${ }^{1}$
}

\section{Full Research Paper}

\section{Address:}

${ }^{1}$ National and Local Collaborative Engineering Center of Chinese Medicinal Resources Industrialization and Formulae Innovative Medicine, Jiangsu Collaborative Innovation Center of Chinese Medicinal Resources Industrialization, Jiangsu Key Laboratory for High Technology Research of TCM Formulae, Nanjing University of Chinese Medicine, Nanjing 210023, China, ${ }^{2}$ Department of Nuclear Medicine, Nanjing First Hospital, Nanjing Medical University, Nanjing 21006, China, ${ }^{3}$ Department of Organic Chemistry, China Pharmaceutical University, Nanjing 211198, China and ${ }^{4}$ College of Pharmacy and Shaanxi Collaborative Innovation Center of Chinese Medicinal Resources Industrialization, Shaanxi University of Chinese Medicine, Xi'an 712046, Shaanxi Province, China

Email:

Nian-Guang Li* - linianguang@njucm.edu.cn; Zhi-Hao Shi* -

sszh163@163.com

* Corresponding author

Keywords:

$\mathrm{C}-\mathrm{H}$ activation; norbornadiene; palladium; phenanthrene derivatives

\author{
Beilstein J. Org. Chem. 2019, 15, 291-298. \\ doi:10.3762/bjoc. 15.26
}

Received: 18 October 2018

Accepted: 18 January 2019

Published: 31 January 2019

Associate Editor: I. Marek

(c) 2019 Zhong et al.; licensee Beilstein-Institut.

License and terms: see end of document.

\begin{abstract}
Herein we report a novel palladium-catalyzed reaction that results in phenanthrene derivatives using aryl iodides, ortho-bromobenzoyl chlorides and norbornadiene in one pot. This dramatic transformation undergoes ortho-C-H activation, decarbonylation and subsequent a retro-Diels-Alder process. Pleasantly, this protocol has a wider substrate range, shorter reaction times and higher yields of products than previously reported methods.
\end{abstract}

\section{Introduction}

Phenanthrene is a polycyclic aromatic hydrocarbon which contains three benzene rings. The phenanthrenes can be used as fundamental building blocks or intermediates in the synthesis of complex natural products such as tuberosinone [1], aristo- lactam Ia [2] and (-)-R-tylophorine [3] (Figure 1). Meanwhile, they also demonstrate a wide range of biological activities including anticancer [4], anti-HIV [5], antibacterial [6], anti-inflammatory [7] and so on. 
<smiles>O=C1Nc2cc3ccc(O)cc3c3c4c(cc(c23)C1=O)OCO4</smiles>

tuberosinone<smiles>O=C1Nc2cc3c(O)cccc3c3c4c(cc(c23)O1)OCO4</smiles>

aristolactam la<smiles>COc1cc2c3c(c4cc(OC)c(OC)cc4c2cc1OC)CN1CCC[C@H]1C3</smiles>

$(-)-R$-tylophorine

Figure 1: Representative natural products containing a phenanthrene moiety.

During the past decades, numerous methods for the preparation of phenanthrene derivatives have been developed. In 2003 , Gabriel Tojo's group reported a base-catalyzed photochemical synthesis of phenanthrene derivatives [8] through intramolecular aromatic coupling (Scheme 1a). Although this method offered an atom-economic and easier strategy for the construction of phenanthrene derivatives, the starting materials in this reaction were difficult to obtain, which limited the development of this approach. Moreover, the ultraviolet light (UV) used in this reaction may cause skin damage to experimenters. Alternatively, alkynes (Scheme 1b) played an important role in the synthesis of phenanthrene scaffolds under transition metal catalysis [9]. However, this protocol required complicated procedures, harsh reaction conditions and was incompatible with

\section{previous work:}

a) Gabriel Tojo's work (2003) [8]<smiles>Cc1ccc(/C=C(/[P-])c2ccc(C)cc2)cc1</smiles>

b) Tamotsu Takahashi's work (2005) [9]<smiles>Brc1ccccc1-c1ccccc1Br</smiles>

1) $n$-BuLi, THF, $-78^{\circ} \mathrm{C}$

2) $\mathrm{CrCl}_{3}, \mathrm{rt}$

3) $\mathrm{Et}-\overline{\overline{\overline{95} \%}} \mathrm{Et}, 12 \mathrm{~h}$<smiles>CCc1c(CC)c2ccccc2c2ccccc12</smiles>

C) Lautens' work (2009) [10]<smiles>[R]c1ccccc1I</smiles><smiles>CC(=O)c1ccccc1Cl</smiles>

$\frac{\mathrm{Pd}(\mathrm{OAc})_{2} \text {, norbornene }}{24 \mathrm{~h}, 70 \%}$<smiles>[R]c1cccc2c1cc(O)c1ccccc12</smiles>

d) Fuk Yee Kwong's work (2017) [11]<smiles></smiles>

this work:<smiles>[R][R]1cccc(I)c1I</smiles><smiles>CC(=O)c1cc[R1]cc1Br</smiles>

$\mathrm{Pd}(\mathrm{OAc})_{2}$, norbornadiene $10 \mathrm{~h}, 98 \%$ $\mathrm{R}^{1} \neq \mathrm{H}$<smiles>[R]c1ccc2c(ccc3ccccc32)c1[R]</smiles>

Scheme 1: Different methods for the synthesis of phenanthrene derivatives. 
many functional groups. Subsequently, facile one-pot approaches had been realized via norbornene-mediated palladium-catalyzed Catellani reaction by Lautens' group [10] (Scheme 1c). Though this strategy was superior to previous methods in terms of mildness of the reaction conditions, it had a limited substrate scope and relatively low reaction efficiency. Very recently, Fuk Yee Kwong and co-workers (Scheme 1d) developed a straightforward one pot $\pi$-extension method using norbornadiene instead of norbornene as directing group to afford the phenanthrenes [11]. However, ortho-haloaryl carboxylic acids employed in this approach had low reactivity, which needed higher reaction temperatures and longer reaction time. Therefore, the development of novel, efficient, and highly functional group tolerant methods for the synthesis of phenanthrene derivatives is still desirable.

Domino reactions such as norbornene-mediated palladium-catalyzed Catellani reactions, which were originally discovered by Catellani in the 1990s [12] and further developed by groups of Catellani and Lautens et al. [13-17], hold great potential for not only settling the sequential reactions in one pot, but also providing access to multisubstituted arenes. In the previous work, we innovatively developed a strategy for the remote $\mathrm{C}-\mathrm{H}$ alkyl- ation of arenes [18]. Recently, our group also achieved aromatic ketones [19] and 2-alkynyl aromatic ketones [20] successfully through ortho-acylation and ipso-Suzuki coupling or alkynylation for the aryl iodides. In this paper, we developed an efficient domino reaction of aryl iodides with ortho-bromobenzoyl chlorides and norbornadiene leading to phenanthrene derivatives, which could be widely used in the synthesis of vital intermediates for functional materials, pharmaceutical agents and natural products.

\section{Results and Discussion}

We initiated our investigations by evaluating the three-component cross-coupling reaction of 2-iodotoluene (1a), orthobromobenzoyl chloride (2a) and norbornadiene, and we optimized the reaction conditions [21]. Firstly, the reaction took place under $\mathrm{Pd}\left(\mathrm{PPh}_{3}\right)_{4} / \mathrm{PPh}_{3}$ as the catalyst, $\mathrm{Cs}_{2} \mathrm{CO}_{3}$ as base, and dimethyl formamide (DMF) as solvent at $105{ }^{\circ} \mathrm{C}$ for $10 \mathrm{~h}$ under $\mathrm{N}_{2}$ atmosphere. Meanwhile, different pallladium species were tested in this reaction system. It was found that $\mathrm{Pd}(\mathrm{OAc})_{2}$ was the most effective palladium catalyst, and the desired product $\mathbf{y}-\mathbf{1}$ was obtained in $98 \%$ yield (Table 1, entries $1-4)$. Next, we studied the influence of different ligands in terms of electron-rich, electron-deficient substituents and steric

Table 1: Optimization of the reaction conditions. ${ }^{a}$<smiles>Cc1ccccc1I</smiles>

$1 \mathrm{a}$<smiles>O=C(Cl)c1ccccc1Br</smiles>

$2 a$
$\operatorname{Pd}(5 \mathrm{~mol} \%)$ ligand (12.5 mol \%) norbornadiene ( 2 equiv) base ( 2.25 equiv) solvent $105^{\circ} \mathrm{C}, 10 \mathrm{~h}$

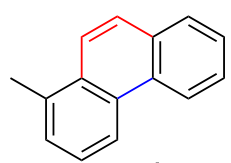

$\mathbf{y - 1}$

\begin{tabular}{|c|c|c|c|c|c|}
\hline entry & catalyst & ligand & base & solvent & yield $[\%]^{b}$ \\
\hline 1 & $\mathrm{Pd}\left(\mathrm{PPh}_{3}\right)_{4}$ & $\mathrm{PPh}_{3}{ }^{\mathrm{C}}$ & $\mathrm{Cs}_{2} \mathrm{CO}_{3}$ & DMF & 86 \\
\hline 2 & $\mathrm{PdCl}_{2}$ & $\mathrm{PPh}_{3}$ & $\mathrm{Cs}_{2} \mathrm{CO}_{3}$ & DMF & 75 \\
\hline 3 & $\mathrm{Pd}(\mathrm{OAc})_{2}$ & $\mathrm{PPh}_{3}$ & $\mathrm{Cs}_{2} \mathrm{CO}_{3}$ & DMF & 98 \\
\hline 4 & $\mathrm{Pd}\left(\mathrm{PPh}_{3}\right)_{2} \mathrm{Cl}_{2}$ & $\mathrm{PPh}_{3}$ & $\mathrm{Cs}_{2} \mathrm{CO}_{3}$ & DMF & 82 \\
\hline 5 & $\mathrm{Pd}(\mathrm{OAc})_{2}$ & TFP $^{d}$ & $\mathrm{Cs}_{2} \mathrm{CO}_{3}$ & DMF & 95 \\
\hline 6 & $\mathrm{Pd}(\mathrm{OAc})_{2}$ & diethyl maleate & $\mathrm{Cs}_{2} \mathrm{CO}_{3}$ & DMF & 94 \\
\hline 7 & $\mathrm{Pd}(\mathrm{OAc})_{2}$ & X-PHOS ${ }^{\mathrm{e}}$ & $\mathrm{Cs}_{2} \mathrm{CO}_{3}$ & DMF & 96 \\
\hline 8 & $\mathrm{Pd}(\mathrm{OAc})_{2}$ & $\mathrm{PPh}_{3}$ & $\mathrm{~K}_{2} \mathrm{CO}_{3}$ & DMF & 95 \\
\hline 9 & $\mathrm{Pd}(\mathrm{OAc})_{2}$ & $\mathrm{PPh}_{3}$ & $\mathrm{CsOAc}$ & DMF & 62 \\
\hline 10 & $\mathrm{Pd}(\mathrm{OAc})_{2}$ & $\mathrm{PPh}_{3}$ & $\mathrm{Et}_{3} \mathrm{~N}$ & DMF & trace \\
\hline 11 & $\mathrm{Pd}(\mathrm{OAc})_{2}$ & $\mathrm{PPh}_{3}$ & DIPEA & DMF & trace \\
\hline 12 & $\mathrm{Pd}(\mathrm{OAc})_{2}$ & $\mathrm{PPh}_{3}$ & $\mathrm{Cs}_{2} \mathrm{CO}_{3}$ & $\mathrm{MeCN}$ & N.D. \\
\hline 13 & $\mathrm{Pd}(\mathrm{OAc})_{2}$ & $\mathrm{PPh}_{3}$ & $\mathrm{Cs}_{2} \mathrm{CO}_{3}$ & toluene & 64 \\
\hline 14 & $\mathrm{Pd}(\mathrm{OAc})_{2}$ & $\mathrm{PPh}_{3}$ & $\mathrm{Cs}_{2} \mathrm{CO}_{3}$ & 1,4-dioxane & 68 \\
\hline 15 & $\mathrm{Pd}(\mathrm{OAc})_{2}$ & $\mathrm{PPh}_{3}$ & $\mathrm{Cs}_{2} \mathrm{CO}_{3}$ & THF & trace \\
\hline 16 & $\mathrm{Pd}(\mathrm{OAc})_{2}$ & $\mathrm{PPh}_{3}$ & $\mathrm{Cs}_{2} \mathrm{CO}_{3}$ & DMAC & 92 \\
\hline
\end{tabular}

aReaction conditions: 1a (0.3 mmol, 1.0 equiv), 2a ( $0.36 \mathrm{mmol}, 1.2$ equiv), norbornadiene ( $0.6 \mathrm{mmol}, 2.0$ equiv), Pd (5 mol \%), ligand (12.5 mol \%),

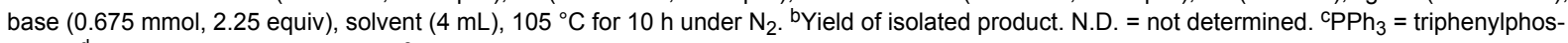

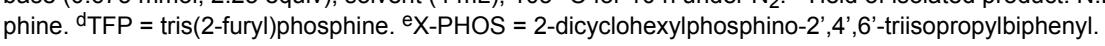


hindrance. The results suggested that different ligands had little effect on this reaction (Table 1, entries 5-7). After a further opimization of various bases, we found that $\mathrm{K}_{2} \mathrm{CO}_{3}$ owned a slimilar reactivity as $\mathrm{Cs}_{2} \mathrm{CO}_{3}$, while $\mathrm{CsOAc}$ with weaker alkalinity showed a lower activity than $\mathrm{K}_{2} \mathrm{CO}_{3}$, giving a yield of $62 \%$ (Table 1, entries 8 and 9). Besides, organic bases such as $\mathrm{Et}_{3} \mathrm{~N}$ and $N, N$-diisopropylethylamine (DIPEA) were not effective for this reaction (Table 1, entries 10 and 11). Furthermore, different solvents were then tested, including $\mathrm{MeCN}$, toluene, 1,4-dioxane, tetrahydrofuran (THF), and dimethylacetamide (DMAC), and we found the yield of $\mathbf{y - 1}$ was inferior to that done by DMF (Table 1, entries 12-16).

With the optimum reaction conditions in hand (Table 1, entry 3 ), we expanded the aryl iodide substrates of this reaction (Scheme 2). As a result, it was found that both electron-deficient and electron-rich aryl iodides progressed well in the transformation, and the yield of relevant phenanthrene derivatives $\mathbf{y - 2}-\mathbf{y}-\mathbf{1 5}$ was quite well. Therefore, it is speculated that the intrinsic electronic properties of aryl iodides makes no differ- ence in this process. The reaction of methoxy-, 2-ethyl-, 2-isopropyl, and 2-phenyliodobenzenes in this procedure afforded the desired products in excellent yields ( $\mathbf{y}-\mathbf{3}, \mathbf{y}-\mathbf{5}, \mathbf{y}-\mathbf{6}$ and $\mathbf{y}-\mathbf{4})$, while 1-iodonaphthalene gave a relative low yield of $64 \%$ (y-2). Gratifyingly, the reaction of disubstituted iodine substrates proceeded smoothly to deliver targeted compounds $\mathbf{y}-\mathbf{7}, \mathbf{y}-\mathbf{8}$, $\mathbf{y - 1 4}$ and $\mathbf{y - 1 5}$ as well. Introducing electron-withdrawing groups at the ortho-position of aryl iodides, such as nitro, fluorine, chlorine, trifluoromethyl and ester, gave $75-95 \%$ yields of the corresponding products $\mathbf{y - 9}-\mathbf{y}-\mathbf{1 3}$, which were precursors for further transition metal-catalyzed cross-coupling reactions.

To further explore the generality of this reaction, different substituted ortho-bromobenzoyl chlorides were then tested (Scheme 3). The ortho-bromobenzoyl chlorides possessing electron-donating groups, such as methyl and methoxy, were well tolerated in this transformation, and the targeted components were acquired in excellent yields (z-1 and $\mathbf{z}-\mathbf{2})$. Notably, ortho-bromobenzoyl chlorides with electron-withdrawing substituents were also compatible substrates, which afforded the<smiles></smiles>

1<smiles>O=C(Cl)c1ccccc1Br</smiles>

$2 a$

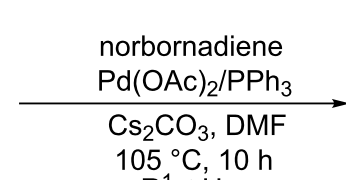

$\mathrm{R}^{1} \neq \mathrm{H}$

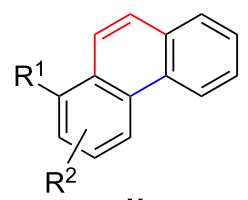

y<smiles>c1ccc2c(c1)ccc1c3ccccc3ccc21</smiles>

y-2, $64 \%$<smiles>CC(C)c1cccc2c1ccc1ccccc12</smiles>

y-6, $90 \%$<smiles>FC(F)(F)c1cccc2c1ccc1ccccc12</smiles>

y-10, $95 \%$<smiles>COc1cccc2c1ccc1ccccc12</smiles>

y-3, $93 \%$<smiles>Cc1ccc2c(ccc3ccccc32)c1C</smiles>

y-7, $87 \%$<smiles>Fc1cccc2c1ccc1ccccc12</smiles>

$y-11,87 \%$<smiles>c1ccc(-c2cccc3c2ccc2ccccc23)cc1</smiles>

$y-4,88 \%$<smiles>Cc1ccc([N+](=O)[O-])c2c1ccc1ccccc12</smiles>

y-8, $85 \%$<smiles>Clc1cccc2c1ccc1ccccc12</smiles>

y-12, $86 \%$<smiles>Cc1cc(F)cc2c1ccc1ccccc12</smiles><smiles>CCc1cccc2c1ccc1ccccc12</smiles>

y-5, $91 \%$<smiles>O=[N+]([O-])c1cccc2c1ccc1ccccc12</smiles>

y-9, $75 \%$<smiles>COC(=O)c1cccc2c1ccc1ccccc12</smiles>

y-13, $94 \%$<smiles>Cc1cc(C)c2ccc3ccccc3c2c1</smiles>

$y-14,95 \%$ 


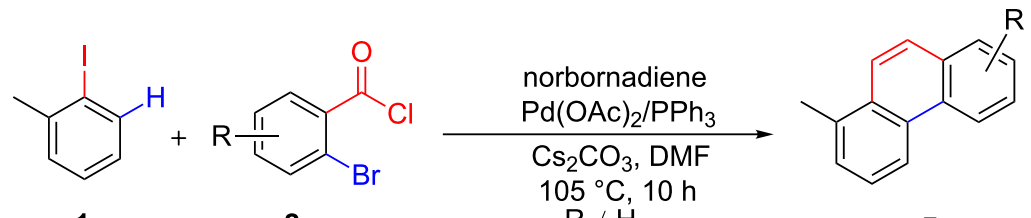

$1 a$

2

$\mathrm{R} \neq \mathrm{H}$

$\mathbf{z}$<smiles>COc1ccc2c(ccc3c(C)cccc32)c1</smiles>

z-1, $94 \%$<smiles>Cc1cccc2c1ccc1cc(F)ccc12</smiles>

$z-4,85 \%$<smiles>Cc1ccc2c(ccc3c(C)cccc32)c1</smiles>

z-2, $91 \%$<smiles>Cc1cccc2c1ccc1cc(Cl)ccc12</smiles>

z-5, $87 \%$<smiles>Cc1cccc2c1ccc1cc(C(F)(F)F)ccc12</smiles>

z-3, $82 \%$<smiles>COc1cc2ccc3c(C)cccc3c2cc1OC</smiles>

z-6, 95\%

Scheme 3: Scope of the reaction in terms of ortho-bromobenzoyl chlorides. Reaction conditions: 1a ( $0.3 \mathrm{mmol}, 1.0$ equiv), 2 ( $0.36 \mathrm{mmol}, 1.2$ equiv), norbornadiene (0.6 mmol, 2.0 equiv), $\mathrm{Pd}(\mathrm{OAC})_{2}(5 \mathrm{~mol} \%), \mathrm{PPh}_{3}$ (12.5 mol \%), $\mathrm{Cs}_{2} \mathrm{CO}_{3}\left(0.675 \mathrm{mmol}, 2.25\right.$ equiv), $\mathrm{DMF}(4 \mathrm{~mL}), 105^{\circ} \mathrm{C}$ for $10 \mathrm{~h}$ under $\mathrm{N}_{2}$.

corresponding products in $82-87 \%$ yield $(\mathbf{z - 3}-\mathbf{z - 5})$. At the same time, a disubstituted substrate was tolerated well to this conversion (z-6). However, the substrates containing ortho-substituents were disadvantageous for this reaction, and none of the desired products was obtained, which indicated that the reaction was strongly influenced by steric hindrance.

It was noteworthy that this sequential one-pot reaction could be carried out on the gram scale (Scheme 4). We selected 2-iodotoluene and 2-bromo-4,5-dimethoxybenzoyl chloride as substrates. When the reaction of 2-iodotoluene (1a, $3.0 \mathrm{mmol}$, 1.0 equiv, $0.654 \mathrm{~g})$, 2-bromo-4,5-dimethoxybenzoyl chloride (3.6 mmol, 1.2 equiv, $1.006 \mathrm{~g})$, and norbornadiene $(6.0 \mathrm{mmol}$, 2.0 equiv, $0.553 \mathrm{~g}$ ) was performed in the presence of $0.15 \mathrm{mmol}$ of $\mathrm{Pd}(\mathrm{OAc})_{2}, 0.375 \mathrm{mmol}$ of $\mathrm{PPh}_{3}$ and $6.75 \mathrm{mmol}$ of $\mathrm{Cs}_{2} \mathrm{CO}_{3}$ at $105{ }^{\circ} \mathrm{C}$ in DMF under $\mathrm{N}_{2}$ for $30 \mathrm{~h}$, the desired compound $\mathbf{z}-6$ was isolated in $88 \%$ yield.
Based on the above experimental results and the use of norbornadiene in Catellani reactions followed by retro-Diels-Alder reaction firstly reported by Lautens et al. [22-24], which is mentioned in recent works [11], a proposed mechanism for this domino reaction is presented in Scheme 5. As is commonly considered, the aryl-Pd ${ }^{\mathrm{II}}$ complex $\mathbf{A}$ is formed by oxidative addition of aryl iodide to the $\mathrm{Pd}^{0}$ complex, which is followed by the insertion of norbornadiene to the $\mathrm{C}-\mathrm{Pd}$ bond of $\mathbf{A}$ to produce $\mathbf{B}$. Then, an ortho- $\mathrm{C}-\mathrm{H}$ activation reaction occurs to $\mathbf{B}$, which offers compound $\mathbf{C}$ with a five-membered palladacycle. $\mathbf{C}$ undergoes the process of oxidative addition with orthobromobenzoyl chloride to give the $\mathrm{Pd}^{\mathrm{IV}}$ intermediate $\mathbf{D}$, and $\mathbf{E}$ can be obtained via a reductive elimination reaction. A novel aryl-Pd ${ }^{\mathrm{II}}$ species $\mathbf{F}$ is formed through removing carbon monoxide from $\mathbf{E}$. Ultimately, $\mathbf{G}$ will experience immediate retroDiels-Alder reaction after the catalytic cycle to afford the target product while taking off cyclopentadiene.<smiles>COc1cc(C(=O)Cl)c(Br)cc1OCc1cccc(O)c1I</smiles><smiles>COc1cc2ccc3c(C)cccc3c2cc1OC</smiles>

$\mathbf{z - 6}, 88 \%$ 


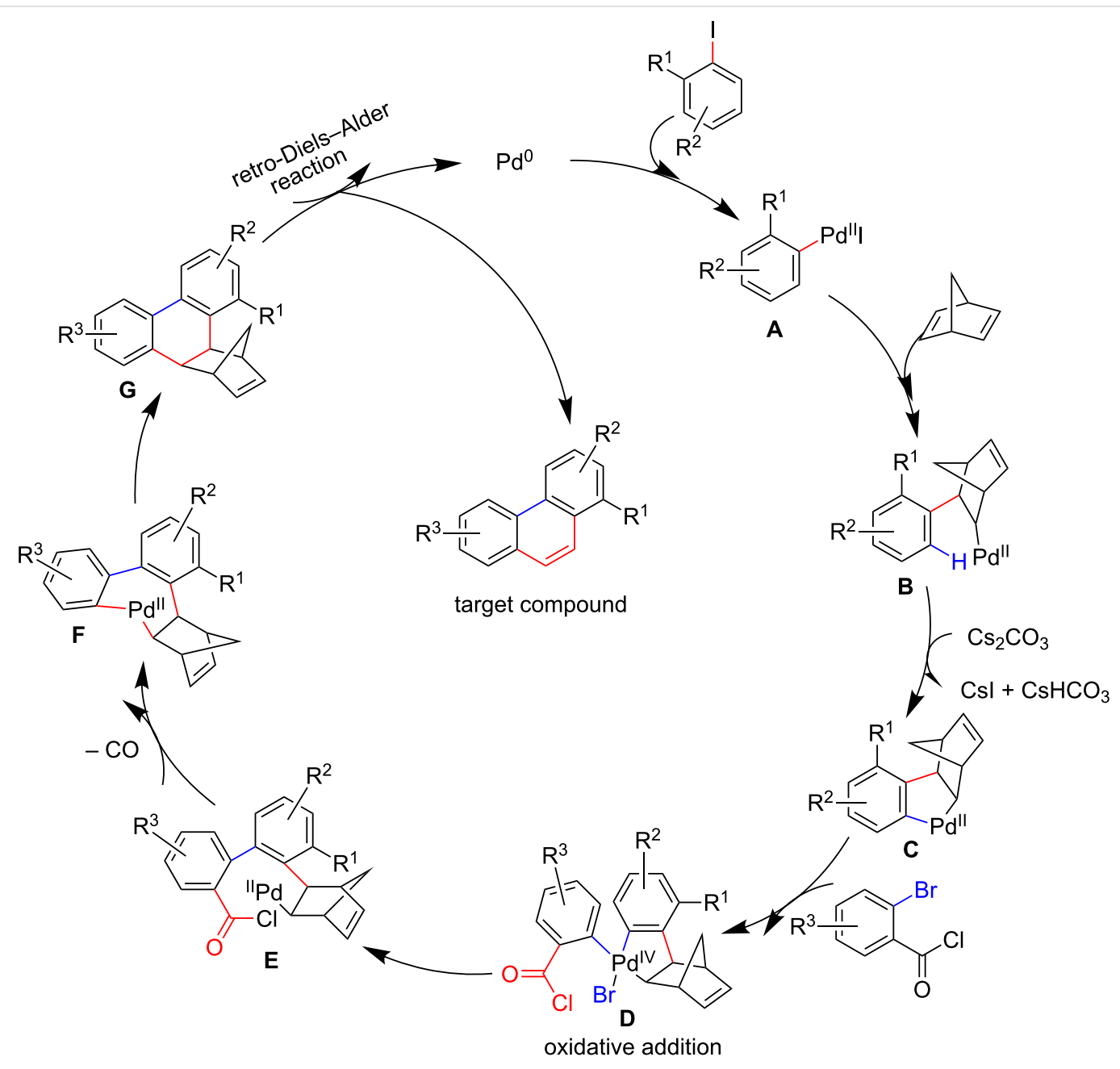

Scheme 5: Proposed mechanism for the formation of phenanthrene derivatives.

\section{Conclusion}

In summary, we have developed a novel and efficient protocol which allows us to construct a variety of phenanthrene derivatives starting from aryl iodides, ortho-bromobenzoyl chlorides and norbornadiene in one pot. A wide range of functional groups are compatible with the reaction, including both electron-withdrawing and electron-donating groups. Compared with previous work for the synthesis of the phenanthrenes, this method shows higher reactivity, shorter reaction times, and higher yields of the target compounds. Meanwhile, these flexible approaches to the phenanthrene derivatives would be expected to provide significant references to material chemistry, pharmaceutical agents and natural product synthesis.

\section{Experimental}

\section{General remarks}

All reactions were carried out under a nitrogen atmosphere unless otherwise stated and commercially available reagents were used without further purification. Solvents were purified by standard techniques without special instructions. Thin-layer chromatography (TLC) was performed on GF254 plates, and the spots were monitored through UV light. Flash chromatography was carried out on silica gel 300-400 mesh. ${ }^{1} \mathrm{H}$ and ${ }^{13} \mathrm{C} \mathrm{NMR}$ spectra were recorded in $\mathrm{CDCl}_{3}$ at 500 and $126 \mathrm{MHz}$, respectively, using the solvents as internal standards. High-resolution mass spectra were taken on Waters Synapt MS. The peak patterns are indicated as follows: s, singlet; $d$, doublet; t, triplet; $\mathrm{m}$, multiplet; q, quartet. The coupling constants $(J)$ are offered in Hz. The ortho-bromobenzoyl chlorides $\mathbf{2 a}-\mathbf{f}$ were synthesized using the known method [25,26].

\section{General procedure for the preparation of products}

A dried round-bottomed flask was charged with aryl iodide ( $0.30 \mathrm{mmol}, 1.0$ equiv), ortho-bromobenzoyl chlorides (0.36 mmol, 1.2 equiv), norbornadiene ( $0.60 \mathrm{mmol}, 2.0$ equiv), $\mathrm{Pd}(\mathrm{OAc})_{2}(5 \mathrm{~mol} \%)$, triphenylphosphine $(12.5 \mathrm{~mol} \%)$, $\mathrm{Cs}_{2} \mathrm{CO}_{3}$ (0.675 mmol, 2.25 equiv), and DMF (4 mL). The mix- 
ture was stirred at $105{ }^{\circ} \mathrm{C}$ under nitrogen atmosphere for $10 \mathrm{~h}$. After cooling to room temperature, the mixture was diluted with ethyl acetate $(5 \mathrm{~mL})$ and brine $(10 \mathrm{~mL})$, and extracted with ethyl acetate $(3 \times 10 \mathrm{~mL})$. The combined organic phase was washed with brine, dried with anhydrous $\mathrm{Na}_{2} \mathrm{SO}_{4}$, filtered, and concentrated under reduced pressure. The crude product was purified by column chromatography on silica gel (petroleum ether/ethyl acetate as eluent) to afford the target compounds.

\section{Supporting Information}

\section{Supporting Information File 1}

Spectral data of products, and ${ }^{1} \mathrm{H}$ NMR and ${ }^{13} \mathrm{C}$ NMR

spectra for the products.

[https://www.beilstein-journals.org/bjoc/content/

supplementary/1860-5397-15-26-S1.pdf]

\section{Acknowledgements}

This work was financially supported by Natural Science Foundation of Jiangsu Province (BK20151563), the Six Talents Project Funded by Jiangsu Province (2013-YY-010), the Program for Excellent Talents in School of Pharmacy of Nanjing University of Chinese Medicine (15ZYXET-1), the 333 High Level Talents Training Project Funded by Jiangsu Province (BRA2016387), Project Funded by the Priority Academic Program Development of Jiangsu Higher Education Institutions and Project Funded by the Flagship Major Development of Jiangsu Higher Education Institutions (PPZY2015A070), the Key Laboratory of Therapeutic Material of Chinese Medicine, Jiangsu Province, State Key Laboratory Cultivation Base for TCM Quality and Efficacy, Nanjing University of Chinese Medicine.

\section{References}

1. Holzbach, J. C.; Nascimento, I. R.; Lopes, L. M. X. J. Braz. Chem. Soc. 2017, 28, 2275-2279. doi:10.21577/0103-5053.20170059

2. Priestap, H. A.; Torres, M. C.; Rieger, R. A.; Dickman, K. G.; Freshwater, T.; Taft, D. R.; Barbieri, M. A.; Iden, C. R. Chem. Res. Toxicol. 2012, 25, 130-139. doi:10.1021/tx200333g

3. Li, R.; Liu, C.-F.; Yu, C.-J.; Gu, P. Tetrahedron Lett. 2018, 59 , 2170-2172. doi:10.1016/j.tetlet.2018.04.052

4. Chemler, S. R. Curr. Bioact. Compd. 2009, 5, 2-19. doi:10.2174/157340709787580928

5. Balzarini, J.; François, K. O.; Van Laethem, K.; Hoorelbeke, B.; Renders, M.; Auwerx, J.; Liekens, S.; Oki, T.; Igarashi, Y.; Schols, D. Antimicrob. Agents Chemother. 2010, 54, 1425-1435. doi:10.1128/aac.01347-09

6. Suliman Mohamed, M.; Timan Idriss, M.; Khedr, A. I. M.; Abd AIGadir, H.; Takeshita, S.; Shah, M. M.; Ichinose, Y.; Maki, T. Int. J. Bacteriol. 2014, No. 481686. doi:10.1155/2014/481686
7. Wen, T.; Wang, Z.; Meng, X.; Wu, M.; Li, Y.; Wu, X.; Zhao, L.; Wang, P.; Yin, Z.; Li-Ling, J.; Wang, Q. ACS Med. Chem. Lett. 2014, 5, 1027-1031. doi:10.1021/ml500255j

8. Almeida, J. F.; Castedo, L.; Fernández, D.; Neo, A. G.; Romero, V.; Tojo, G. Org. Lett. 2003, 5, 4939-4941. doi:10.1021/ol0357954

9. Kanno, K.-i.; Liu, Y.; lesato, A.; Nakajima, K.; Takahashi, T. Org. Lett. 2005, 7, 5453-5456. doi:10.1021/ol052214x

10. Zhao, Y.-B.; Mariampillai, B.; Candito, D. A.; Laleu, B.; Li, M.; Lautens, M. Angew. Chem., Int. Ed. 2009, 48, 1849-1852. doi:10.1002/anie.200805780

11. Fu, W. C.; Wang, Z.; Chan, W. T. K.; Lin, Z.; Kwong, F. Y. Angew. Chem., Int. Ed. 2017, 56, 7166-7170. doi:10.1002/anie.201703551

12. Catellani, M.; Frignani, F.; Rangoni, A. Angew. Chem., Int. Ed. 1997, 36, 119-122. doi:10.1002/anie.199701191

13. Faccini, F.; Motti, E.; Catellani, M. J. Am. Chem. Soc. 2004, 126, 78-79. doi:10.1021/ja039043g

14. Motti, E.; Faccini, F.; Ferrari, I.; Catellani, M.; Ferraccioli, R. Org. Lett. 2006, 8, 3967-3970. doi:10.1021/ol061443w

15. Lautens, M.; Paquin, J.-F.; Piguel, S. J. Org. Chem. 2002, 67, 3972-3974. doi:10.1021/jo025730z

16. Pache, S.; Lautens, M. Org. Lett. 2003, 5, 4827-4830. doi:10.1021/ol035806t

17. Ye, J.; Shi, Z.; Sperger, T.; Yasukawa, Y.; Kingston, C.; Schoenebeck, F.; Lautens, M. Nat. Chem. 2017, 9, 361-368. doi:10.1038/nchem.2631

18. Cheng, H.-G.; Wu, C.; Chen, H.; Chen, R.; Qian, G.; Geng, Z.; Wei, Q.; Xia, Y.; Zhang, J.; Zhang, Y.; Zhou, Q. Angew. Chem., Int. Ed. 2018, 57, 3444-3448. doi:10.1002/anie.201800573

19. Wu, W.; Yu, S.; Gu, T.; Fan, T.; Zhong, Y.; Li, N.; Tang, Y.; Jiang, Y.; Zhu, X.; Duan, J.; Shi, Z. Eur. J. Org. Chem. 2018, 3075-3085. doi:10.1002/ejoc.201800363

20. Yu, S.-P.; Zhong, Y.; Gu, T.; Wu, W.-Y.; Fan, T.-Y.; Li, N.-G.; Shi, Z.-H.; Tang, Y.-P.; Duan, J.-A. Tetrahedron 2018, 74, 5942-5949. doi:10.1016/j.tet.2018.08.027

21. Della Ca', N.; Maestri, G.; Malacria, M.; Derat, E.; Catellani, M. Angew. Chem., Int. Ed. 2011, 50, 12257-12261. doi:10.1002/anie.201104363

22. Hulcoop, D. G.; Lautens, M. Org. Lett. 2007, 9, 1761-1764. doi:10.1021/ol070475w

23. Catellani, M.; Motti, E.; Della Ca', N. Acc. Chem. Res. 2008, 41, 1512-1522. doi:10.1021/ar800040u

24. Cheng, M.; Yan, J.; Hu, F.; Chen, H.; Hu, Y. Chem. Sci. 2013, 4, 526-530. doi:10.1039/c2sc21335d

25. Hu, Q.-F.; Gao, T.-T.; Shi, Y.-J.; Lei, Q.; Yu, L.-T. RSC Adv. 2018, 8, 13879-13890. doi:10.1039/c8ra02099j

26. Lou, Z.; Man, N.; Yang, H.; Zhu, C.; Fu, H. Synlett 2018, 29 , 1395-1399. doi:10.1055/s-0036-1591565 


\section{License and Terms}

This is an Open Access article under the terms of the Creative Commons Attribution License (http://creativecommons.org/licenses/by/4.0). Please note that the reuse, redistribution and reproduction in particular requires that the authors and source are credited.

The license is subject to the Beilstein Journal of Organic Chemistry terms and conditions:

(https://www.beilstein-journals.org/bjoc)

The definitive version of this article is the electronic one which can be found at:

doi:10.3762/bjoc. 15.26 